\title{
Aktivitas nokturnal vektor demam berdarah dengue di beberapa daerah di Indonesia
}

\author{
Nocturnal biting activity of dengue vectors \\ in several areas of Indonesia
}

\author{
Upik Kesumawati Hadi*, Susi Soviana, Dwi Djayanti Gunandini \\ Bagian Parasitologi \& Entomologi Kesehatan, Departemen Ilmu Penyakit Hewan dan \\ Kesehatan Masyarakat Veteriner Fakultas Kedokteran Hewan IPB Bogor. \\ Jalan Agatis Kampus Darmaga IPB Bogor 16880
}

(diterima Desember 2011, disetujui Maret 2012)

\begin{abstract}
ABSTRAK
Infeksi virus dengue terus menerus menjadi masalah kesehatan yang serius di berbagai daerah tropis di dunia karena sering berakibat fatal pada anak-anak. Virus dengue ditularkan ke manusia melalui gigitan nyamuk, terutama Aedes aegypti dan Aedes albopictus yang terinfeksi virus. Makalah ini melaporkan aktivitas menggigit malam hari (nokturnal) Ae. aegypti dan Ae. albopictus di beberapa daerah di Indonesia. Nyamuk Aedes ditangkap dengan metoda umpan badan dan metoda pengumpulan nyamuk istirahat dari pukul 18:00 sampai 06:00 di dalam dan di luar rumah. Hasil pengamatan menunjukkan bahwa aktvitas menggigit nyamuk Ae. aegypti dan Ae. albopictus terjadi sepanjang malam dari pukul 18.00 sampai 05:50 baik di dalam maupun di luar rumah di daerahdaerah Cikarawang, Babakan, dan Cibanteng Kabupaten Bogor (2004); Cangkurawuk Darmaga Bogor (2005, 2007), Pulau Pramuka, Pulau Pari, Kepulauan Seribu (2008), Gunung Bugis, Gunung Karang, Gunung Utara Balikpapan (2009) dan Kayangan, Lombok Utara (2009). Hasil penelitian menunjukkan bahwa aktivitas menggigit nyamuk Ae. aegypti dan Ae. albopictus tidak hanya di siang hari tetapi juga malam hari.
\end{abstract}

Kata kunci: Aedes aegypti, Aedes albopictus, aktivitas menggigit malam hari

\begin{abstract}
The continous presence of dengue virus infection presents a serious health problem in many tropical areas of the world because of the severe and often fatal disease in children. Dengue viruses are transmitted to human through the biting of infected mosquitoes, especially Aedes aegypti and Aedes albopictus. This paper reported the nocturnal of biting activity of Ae. aegypti and Ae. albopictus in several areas of Indonesia. Natural population of Aedes was collected by bare leg collection and resting collection from 18:00 to 06:00 out door and indoor. The biting activities of Ae. aegypti and Ae. albopictus occurred throughout the night from 18:00 to 05:50 out door and indoor in Cikarawang, Babakan, and Cibanteng Kabupaten Bogor (2004); Cangkurawuk Darmaga Bogor (2005, 2007); Pramuka island, Pari island, Kepulauan Seribu (2008); Gunung Bugis, Gunung Karang, Gunung Utara Balikpapan (2009); and Kayangan, Lombok Utara (2009). These results showed that the biting activities of Ae. aegypti dan Ae. albopictus did not only occur diurnally but also nocturnally.
\end{abstract}

Key words: Aedes aegypti, Aedes albopictus, nocturnal biting activity

\footnotetext{
${ }^{*}$ Penulis korespondensi: Upik K. Hadi. Bagian Parasitologi \& Entomologi Kesehatan, Departemen Ilmu Penyakit Hewan dan Kesehatan Masyarakat Veteriner, Fakultas Kedokteran Hewan, IPB, Jalan Agatis Kampus Darmaga IPB Bogor 16880 Tel: 0251-8421784, Email: upikke@ipb.ac.id
} 


\section{PENDAHULUAN}

Kasus demam berdarah dengue (BDB) sudah menjadi perhatian internasional dengan jumlah kasus di seluruh dunia mencapai 50 juta pertahun. Penyakit DBD disebabkan oleh satu dari empat bahan antigenik yang dikenal serotipe 1-4 (virus DEN-1, DEN-2, DEN-3 dan DEN-4) dari genus Flavivirus, famili Flaviridae. Infeksi dengan satu dari empat serotipe ini tidak menyediakan kekebalan protektif silang, sehingga orang yang tinggal di daerah endemik dapat tertular oleh empat infeksi virus sepanjang waktu (Westway et al. 1985). Aedes aegypti dan Aedes albopictus adalah vektor penular penyakit DBD. Ae. aegypti menempati habitat domestik terutama penampungan air di dalam rumah yang tidak berhubungan dengan tanah, sedangkan Ae. albopictus berkembang biak di lubang-lubang pohon, drum, ban bekas yang terdapat di luar (peridomestik) (WHO 2004; Chan 1985) melaporkan bahwa di daerah perkotaan habitat Ae. aegypti dan Ae. albopictus sangat bervariasi tetapi $90 \%$ adalah wadah-wadah buatan manusia. Wadah air buatan manusia merupakan habitat Ae. aegypti yang potensial di perkotaan (Gratz 1993). Ae. aegypti aktif menghisap darah pada siang hari (diurnal) dengan dua puncak gigitan yaitu jam 08:00-09:00 dan jam 16:00-17:00 (Christophers 1960; Hadi \& Koesharto 2006).

DBD masuk ke Indonesia pertama kali pada tahun 1968, di kota Jakarta dan Surabaya (Bang \& Shah 1986). Sejak itu penyakit ini meningkat terus hingga kini, seolah tidak dapat dikendalikan, meskipun berbagai upaya sudah dilakukan, dari mulai penanganan penderita, gerakan Pemberantasan Sarang Nyamuk (PSN), fogging (pengasapan) dan sebagainya. Berbagai pertanyaan muncul mengapa demikian, apakah virus sudah mutasi, apakah nyamuk sudah berubah perilaku, apakah akibat pemanasan global, atau ada penyebab lain.

Tulisan ini melaporkan beberapa fakta yang menunjukkan bahwa vektor demam berdarah aktif menghisap darah orang di malam hari (nokturnal).

\section{BAHAN DAN METODE}

Penelitian dilakukan di wilayah permukiman lingkar kampus IPB Darmaga, Bogor (2004, 2005, 2007), Pulau Pramuka dan Pulau Pari (2008),
Balikpapan (2009), dan Kayangan Lombok (2009). Penangkapan nyamuk dilakukan dengan cara bare leg collection (umpan badan orang) dan resting collection (nyamuk istirahat) dari jam 18:00 sampai dengan jam 06:00 di dalam dan di luar rumah (WHO 1975). Penangkapan nyamuk dilakukan dengan cara kolektor umpan duduk di dalam atau di luar rumah. Celana kolektor digulung sampai lutut, dan jika ada nyamuk hinggap atau menggigit, nyamuk ditangkap dengan menggunakan aspirator. Penangkapan nyamuk dilakukan oleh enam orang kolektor pada tiga rumah, masing-masing rumah terdiri atas satu kolektor di dalam rumah dan satu orang di luar rumah. Setiap jam penangkapan terdiri atas 50 menit, 10 menit digunakan untuk menangkap nyamuk istirahat di dinding dan sekitarnya. Nyamuk yang tertangkap dimasukkan dalam gelas kertas dan dibedakan setiap jam. Nyamuk yang tertangkap kemudian diidentifikasi di bawah mikroskop.

\section{HASIL}

Hasil pengamatan dari beberapa daerah di wilayah Indonesia dari tahun 2004 hingga 2009 memperlihatkan adanya aktivitas nokturnal pada Ae. aegypti dan Ae. albopictus. Tabel 1 menunjukkan secara rinci aktivitas nokturnal kedua jenis nyamuk tersebut tertangkap menghisap darah di beberapa daerah penelitian ketika dilakukan penangkapan nyamuk nokturnal lain yang berkaitan dengan perannya sebagai vektor malaria dan filaria.

Di Babakan, Cikarawang dan Cibanteng Kabupaten Bogor pada tahun 2004, nyamuk Ae. aegypti dan Ae. albopictus ditemukan menghisap darah di dalam rumah dan di luar rumah pada jam 18:00 hingga 20:50. Di Cangkurawuk, Darmaga Kabupaten Bogor pada tahun 2005 dan 2007, kedua jenis tersebut juga ditemukan lagi tertangkap menghisap darah di dalam rumah dan di luar rumah pada jam 21:00 hingga 02:50.

Di Pulau Pramuka dan Pulau Pari, Kepulauan Seribu DKI Jakarta pada tahun 2008 Ae. aegypti dan Ae. albopictus ditemukan menghisap darah di dalam rumah dan di luar rumah pada jam 18:00 hingga 20:50, dan pada jam 21:00-23:50 juga masih ditemukan meskipun jumlahnya sudah berkurang dibandingkan dengan pada awal malam (Tabel 1). 
Tabel 1. Jumlah nyamuk Aedes aegypti dan Aedes albopictus yang tertangkap menghisap darah pada malam hari di beberapa daerah di Indonesia

\begin{tabular}{lccccc}
\hline \multirow{2}{*}{$\begin{array}{l}\text { Lokasi \& waktu } \\
\text { penelitian }\end{array}$} & $\begin{array}{c}\text { Jam } \\
\text { penangkapan }\end{array}$ & \multicolumn{2}{c}{$\begin{array}{c}\text { Jumlah Ae. aegypti yang } \\
\text { tertangkap di: }\end{array}$} & \multicolumn{2}{c}{$\begin{array}{c}\text { Jumlah Ae. albopictus yang } \\
\text { tertangkap di: }\end{array}$} \\
& Dalam & Luar & Dalam & Luar \\
\hline $\begin{array}{l}\text { Cikarawang, Babakan, } \\
\text { Cibanteng, Bogor }\end{array}$ & $18: 00-20: 50$ & 2 & 4 & 1 & 6 \\
April-Juni 2004 & & & & & \\
Cangkurawuk, & $21: 00-23: 50$ & 2 & 0 & 1 & 3 \\
Darmaga, Bogor & $24: 00-02: 50$ & 2 & 1 & 2 & 1 \\
Juni 2005 & & & & & \\
Cangkurawuk, & $21: 00-23: 50$ & 2 & 0 & 1 & 0 \\
Darmaga, Bogor & $24: 00-02: 50$ & 5 & 1 & 2 & 1 \\
November 2007 & & & & & \\
P.Pramuka, P.Pari & $18: 00-20: 50$ & 0 & 3 & 0 & 4 \\
Kep Seribu & $21: 00-23: 50$ & & & & \\
21-25 Mei 2008 & & & & 19 & 70 \\
Gunung Bugis, & $18: 00-20: 50$ & 5 & 11 & 7 & 41 \\
G.Karang, G.Utara & $21: 00-23: 50$ & 2 & 8 & 6 & 34 \\
Balikpapan & $24: 00-02: 50$ & 3 & 1 & 0 & 6 \\
21-23 Januari 2009 & $03: 00-05: 50$ & 1 & 1 & 1 & 0 \\
Kayangan, Lombok & $18: 00-20: 50$ & 1 & 1 & 1 & 1 \\
Utara & $21: 00-23: 50$ & 0 & 0 & 1 & 1 \\
Juni 2009 & $24: 00-02: 50$ & 2 & 0 & & \\
\hline
\end{tabular}

Tabel 2. Jumlah nyamuk Aedes aegypti dan Aedes albopictus yang tertangkap sedang beristirahat pada malam hari di Balikpapan

\begin{tabular}{lccccc}
\hline \multirow{2}{*}{$\begin{array}{l}\text { Lokasi \& waktu } \\
\text { penelitian }\end{array}$} & \multirow{2}{*}{$\begin{array}{c}\text { Jam } \\
\text { penangkapan }\end{array}$} & \multicolumn{2}{c}{$\begin{array}{c}\text { istirahat di: } \\
\text { Dalam }\end{array}$} & Luar & \multicolumn{2}{c}{$\begin{array}{c}\text { Jumlah Ae. albopictus yang } \\
\text { istirahat di: }\end{array}$} \\
& & Dalam & Luar \\
\hline Gunung Bugis, & $18: 00-20: 50$ & 1 & 0 & 0 & 0 \\
Balikpapan & $21: 00-23: 50$ & 0 & 1 & 0 & 1 \\
21-23 Januari 2009 & $24: 00-02: 50$ & 0 & 0 & 0 & 0 \\
& $03: 00-05: 50$ & 1 & 1 & 0 & 1 \\
Gunung Karang, & $18: 00-20: 50$ & 0 & 1 & 5 & 37 \\
Balikpapan & $21: 00-23: 50$ & 0 & 6 & 2 & 12 \\
21-23 Januari 2009 & $24: 00-02: 50$ & 0 & 0 & 1 & 5 \\
& $03: 00-05: 50$ & 0 & 0 & 0 & 10 \\
Gunung Utara, & $18: 00-20: 50$ & 0 & 0 & 2 & 0 \\
Balikpapan & $21: 00-23: 50$ & 1 & 0 & 25 & 1 \\
21-23 Januari 2009 & $24: 00-02: 50$ & 0 & 0 & 1 & 1 \\
& $03: 00-05: 50$ & 1 & 0 & 0 & 0 \\
\hline
\end{tabular}

Saat itu juga ditemukan jenis nyamuk nokturnal lainnya yang banyak ditemukan menghisap darah di wilayah pengamatan ini.

Sementara itu, di daerah permukiman perusahaan E \& P Total, Balikpapan pada Januari 2009, Ae. aegypti dan Ae. albopictus ditemukan aktif menghisap darah di malam hari dalam jumlah yang cukup banyak daripada daerah lain. Kedua jenis nyamuk ini aktif menghisap darah di dalam rumah dan di luar rumah dari jam 18:00 hingga 05:50, dengan jumlah nyamuk terbanyak antara jam 19:00 hingga 23:50, kemudian menurun bersamaan dengan larutnya malam. Demikian pula halnya dengan Ae. aegypti dan Ae. albopictus yang tertangkap di wilayah permukiman Desa Kayangan, Lombok Utara. Pada daerah tersebut 
nyamuk Aedes tertangkap hingga jam 05:50, meskipun jumlahnya tidak sebanyak di Balikpapan.

Di Balikpapan nyamuk Aedes ditemukan juga dalam keadaan istirahat baik di dinding rumah, gantungan baju, dan lainnya di dalam rumah maupun di luar rumah. Di Gunung Bugis, jumlah nyamuk yang istirahat di dalam dan di luar rumah lebih sedikit dibandingkan dengan di Gunung Karang dan Gunung Utara. Di Gunung Karang Ae. albopictus tertangkap sedang istirahat di luar rumah dalam jumlah lebih banyak (37) daripada di dalam rumah dari jam 18:00 sampai 02:50. Di Gunung Utara Ae. albopictus terbanyak (25) tertangkap istirahat di dalam rumah pada jam 21:00-23:50 (Tabel 2).

\section{PEMBAHASAN}

Berdasarkan fakta temuan di atas, Ae. aegypti dan Ae. albopictus ternyata dapat menghisap darah pada malam hari (nokturnal). Padahal sejauh ini diketahui bahwa Ae. aegypti aktif menghisap darah pada siang hari (diurnal) dengan dua puncak gigitan yaitu pagi hari jam 8:00-9:00 dan sore hari jam 16:00-17:00 (Christophers 1960; Hadi \& Koesharto 2006). Informasi ini dapat menjadi dasar agar pencegahan dari gigitan nyamuk ini harus dilakukan tidak hanya pada siang hari, tetapi juga malam hari.

Fenomena perubahan perilaku pada vektor demam berdarah ini tidak hanya dari temuan aktifitas nokturnal tetapi juga terhadap perkembangbiakan larvanya. Teori menunjukkan bahwa Ae. aegypti menempati habitat domestik terutama penampungan air di dalam rumah yang tidak berhubungan dengan tanah, sedangkan Ae. albopictus berkembang biak di lubang-lubang pohon, drum, ban bekas yang terdapat di luar (peridomestik) (WHO 2003; 2004). Hasil pengamatan penelitian pendahuluan Hadi et al. (unpublished data, 2000) menunjukkan adanya indikasi perubahan perilaku larva nyamuk Ae. aegypti yaitu mampu berkembangbiak pada wadah yang berisi campuran air dengan feses ayam, campuran air dengan feses sapi dan campuran air dengan kedua jenis feses tersebut di laboratorium. Adanya perubahan perilaku berkembang biak nyamuk yang semula hanya media air yang jernih ini kemudian diteliti lebih mendalam pada tahun 2006. Hasilnya menunjukkan bahwa air terpolusi dapat menjadi tempat perindukan dan berkembangbiak nyamuk Ae. aegypti. Berdasarkan jumlah telur yang diletakkan, Ae. aegypti paling banyak ditemukan pada media air tanah dan paling sedikit pada media air kaporit. Pada media berisi berbagai campuran polutan (kaporit, detergen, feses, dan tanah) $A e$. aegypti bertelur lebih banyak dan mampu menetas 98-100\%. Kemudian, pada media yang hanya berisi air sumur lebih sedikit dan hanya menetas $12-76 \%$. Telur Ae. aegypti juga dapat menetas dan berkembang hingga dewasa dalam berbagai media yang mengandung polutan (Hadi et al. 2009a). Pengamatan nyamuk vektor, seperti Ae. aegypti dan Ae. albopictus sangat penting dilakukan, terutama terhadap penyebaran, dinamika populasi, habitat larva, agar dugaan resiko terjadinya penularan dapat diketahui dan pengendalian vektor di setiap lokasi dapat terlaksana secara maksimal. Fakta menunjukkan bahwa berbagai kasus penyakit demam berdarah juga telah meluas bukan hanya di daerah perkotaan tetapi juga di pedesaan. Sejauh mana sebaran larva Ae. aegypti di daerah pedesaan dan kasus penyakit demam berdarah belum banyak diungkapkan secara ilmiah. Pengamatan penulis pada tahun 1990 di sekitar perumahan dosen di kampus Darmaga hanya ditemukan jenis Ae. albopictus, tetapi pengamatan terakhir (20052007) ditemukan Ae. aegypti sudah mendominasi penampungan air di dalam rumah. Oleh karena itu, daerah tersebut telah tergolong daerah berisiko terkena DBD apabila terdapat warga yang menderita. Hadi et al. (2009b) menunjukkan bahwa Desa Cikarawang, Kecamatan Dramaga Bogor juga merupakan contoh daerah pedesaan yang beresiko terhadap penyakit DBD. Jentik $A e$. aegypti ditemukan di seluruh RW yang terdapat di desa tersebut. Larva Ae. aegypti ditemukan pada $71(13 \%)$ dari 545 rumah, dan pada 78 (6,5\%) dari 1196 wadah yang diperiksa. Angka jentik dalam kontainer (CI), dalam rumah (HI) dan angka breteau (BI) masing-masing adalah 7, 6, 13,4 dan 14,8. Larva paling banyak ditemukan pada wadah air dengan bahan dasar semen (20\%), tetapi berdasarkan jenis wadah larva banyak ditemukan pada tanki air (33,3\%). Warga masyarakat juga banyak yang terkena DBD tanpa melapor ke Puskesmas terdekat.

Hidayati et al. (2007) melaporkan bahwa unsur iklim juga jelas berpengaruh terhadap pertumbuhan dan perkembangan nyamuk pradewasa. Keter- 
sediaan air (yang bersumber dari curah hujan atau selisih hujan dengan evapotranspirasi) dan suhu. Setelah nyamuk dewasa, hal yang mempengaruhi penularan penyakit demam berdarah adalah aktivitas (nyamuk) menghisap darah dan kecepatan replikasi virus penyakit demam berdarah, dan unsur iklim yang paling berpengaruh adalah suhu. Tingkat penyebaran virus yang tinggi terjadi pada peralihan musim dengan curah hujan dan saat suhu udara meningkat. Hasil penelitian menunjukkan bahwa waktu yang dibutuhkan telur nyamuk untuk berubah menjadi dewasa berkurang (makin cepat) dengan bertambahnya suhu udara.

Fakta adanya aktifitas nokturnal pada Ae. aegypti dan Ae. albopictus dapat bermanfaat sebagai informasi dasar dalam penyusunan program pengendalian vektor penyakit demam berdarah di Indonesia. Upaya pencegahan dari gigitan vektor demam berdarah tidak hanya siang hari, tetapi juga malam hari. Untuk mencegah perkembang biakan larva, tidak hanya menghindarkan adanya genangan air jernih tetapi juga air terpolusi yang dapat menjadi tempat perkembangbiakan nyamuk Ae. aegypti. Nyamuk ini tidak hanya tersebar di daerah perkotaan tetapi juga di daerah pedesaan yang umumnya telah beradaptasi dengan suasana perkotaan dalam hal menyediakan tempat-tempat penampungan air baik di dalam maupun di luar rumah. Mobilitas yang tinggi penduduk pedesaan ke daerah perkotaan dapat meningkatkan risiko terjadinya penyakit demam berdarah di daerah pedesaan seperti yang telah dilaporkan di beberapa daerah di Indonesia.

\section{KESIMPULAN}

Aktifitas Ae. aegypti dan Ae. albopictus menghisap darah pada malam hari (nokturnal) dari jam 18:00-05:50 ditemukan di beberapa daerah di Indonesia yaitu Cikarawang, Babakan, dan Cibanteng Kabupaten Bogor (2004), Cangkurawuk Darmaga Bogor (2005, 2007), Pulau Pramuka, Pulau Pari Kepulauan Seribu (2008), Gunung Bugis, Gunung Karang, Gunung Utara Balikpapan (2009) dan Kayangan, Lombok Utara (2009). Hasil penelitian ini menunjukkan bahwa kedua jenis vektor tersebut tidak hanya aktif menghisap darah di siang hari tetapi juga di malam hari.

\section{UCAPAN TERIMA KASIH}

Terima kasih kami sampaikan kepada semua tim yang telah membantu selama penelitian ini berlangsung, mulai dari persiapan, pelaksanaan, hingga proses penulisan.

\section{DAFTAR PUSTAKA}

Bang YH, Shah NK. 1986. Regional review of DHF situation and control of Aedes aegypti in Southeast Asia. Dengue News 12:1-9.

Chan KI. 1985. Singapore's Dengue Haemorrhagic Fever Control Program: A case on study on the Successful Control of Aedes aegypti and Aedes albopictus using Mainly Environmental Measures as a part of Integrated Vector Control. South East Asian Medical Information Center. Tokyo.

Christophers SSR. 1960. Aedes aegypti (L) the yellow fever mosquito. London: Cambridge Univ. Press.

Gratz NG. 1993. Lessons of Aedes aegypti control in Thailand. Journal Medicine Veteriner Entomology 7:1-10. http://dx.doi. org/10.1111/j.1365-2915.1993.tb00644.x.

Hadi UK, Koesharto FX. 2006. Nyamuk. Di dalam: Sigit SH, Hadi UK. (Ed.), Hama Permukiman Indonesia. Pengenalan, Biologi, dan Pengendalian. pp. 23-51. Bogor: Unit Kajian Pengendalian Hama Permukiman. Fakultas Kedokteran Hewan, Institut Pertanian Bogor.

Hadi UK, Agustina E, Sigit SH. 2009a. Habitat perkembangan jentik Aedes aegypti (Diptera: Culicidae) pada berbagai jenis air terpolusi. Di dalam: Prosiding Seminar Nasional Hari Nyamuk (Bogor, 10 Agustus 2009). pp. 143-153. Bogor: APNI.

Hadi UK, Agustina E, Sigit SH. 2009b. Sebaran jentik Aedes aegypti (Diptera: Culicidae) di desa Cikarawang Bogor. Di dalam: Prosiding Seminar Nasional Hari Nyamuk 2009 (Bogor, 10 Agustus 2009). pp. 154-159. Bogor: APNI.

Hidayati R, Hadi UK, Manuwoto S, Koesmaryono Y, Boer R. 2007. Kebutuhan panas untuk fase perkembangan pada nyamuk Aedes aegypti (Diptera: Culicidae) dan periode inkubasi ekstrinsik virus dengue. Jurnal Ekologi Kesehatan 6:648-658. Westway EG, Brinton MA, Gaimoamovich S, Horzink MC, Igarashi A, Kaariainen L. 1985. 
Flaviridae. Intervirologi 24:183-192. http:// dx.doi.org/10.1159/000149642.

WHO. 1975. Manual on practical in malaria part II. Geneva: WHO

WHO. 2003. Prevention and control of dengue and dengue haemorrhagic fever. New Delhi India: WHO Regional Publication SEARO.
WHO. 2004. Dengue alert in South East Asia Region. New Delhi. World Health Organisation. Regional Office for South East Asia. Available at: http://w3.whosea.orga/index.htm [accessed 25 August 2004] 